Article

\title{
Molecular Design and Property Prediction of Sterically Confined Polyimides for Thermally Stable and Transparent Materials
}

\author{
Ki-Ho Nam ${ }^{1,+}$, Hoi Kil Choi ${ }^{1,+}$, Hyeonuk Yeo ${ }^{2}$ (D), Nam-Ho You ${ }^{1}$, Bon-Cheol Ku ${ }^{1, *(D)}$ \\ and Jaesang $\mathrm{Yu}^{1}$,* \\ 1 Institute of Advanced Composite Materials, Korea Institute of Science and Technology (KIST), \\ Jeonbuk 55324, Korea; khnam@kist.re.kr (K.-H.N.); 214011@kist.re.kr (H.K.C.); polymer@kist.re.kr (N.-H.Y.) \\ 2 Department of Chemistry Education, Chemistry Building, Kyungpook National University, 80, Daehak-ro, \\ Buk-gu, Daegu 41566, Korea; yeo@knu.ac.kr \\ * Correspondence: cnt@kist.re.kr (B.-C.K.); jamesyu@kist.re.kr (J.Y.); \\ Tel.: +82-63-219-8132 (B.-C.K.); +82-63-219-8156 (J.Y.) \\ + These authors contributed equally to this paper.
}

Received: 3 May 2018; Accepted: 5 June 2018; Published: 7 June 2018

check for updates

\begin{abstract}
To meet the demand for next-generation flexible optoelectronic devices, it is crucial to accurately establish the chemical structure-property relationships of new optical polymer films from a theoretical point of view, prior to production. In the current study, computer-aided simulations of newly designed poly(ester imide)s (PEsIs) with various side groups $\left(-\mathrm{H},-\mathrm{CH}_{3}\right.$, and $\left.-\mathrm{CF}_{3}\right)$ and substituted positions were employed to study substituent-derived steric effects on their optical and thermal properties. From calculations of the dihedral angle distribution of the model compounds, it was found that the torsion angle of the $\mathrm{C}-\mathrm{N}$ imide bonds was effectively constrained by the judicious introduction of di-, tetra-, and hexa-substituted aromatic diamines with $-\mathrm{CF}_{3}$ groups. A high degree of fluorination of the PEsI repeating units resulted in weaker intra- and intermolecular conjugations. Their behavior was consistent with the molecular orbital energies obtained using density functional theory (DFT). In addition, various potential energy components of the PEsIs were investigated, and their role in glass-transition behavior was studied. The van der Waals energy $\left(E_{\mathrm{vdW}}\right)$ played a crucial role in the segmental chain motion, which had an abrupt change near glass-transition temperature $\left(T_{\mathrm{g}}\right)$. The more effective steric effect caused by $-\mathrm{CF}_{3}$ substituents at the 3-position of the 4 -aminophenyl group significantly improved the chain rigidity, and showed high thermal stability $\left(T_{\mathrm{g}}>731 \mathrm{~K}\right)$ when compared with the $-\mathrm{CH}_{3}$ substituent at the same position, by highly distorting $\left(89.7^{\circ}\right)$ the conformation of the main chain.
\end{abstract}

Keywords: poly(ester imide); substituent effect; glass-transition temperature; molecular dynamics simulation; optical property

\section{Introduction}

In recent years, interest grew in the development of thin, lightweight, and unbreakable new-generation optoelectronic devices, with transparent flexible plastic substrates for portable devices, and roll-up and conformable displays [1,2]. At the same time, to meet the market demand for optical devices with high reliability, high integration, and rapid signal-transmission speeds, the service temperature requirements of the plastic substrates increased dramatically $[3,4]$. The flexible plastic substrate must be able to withstand the high temperatures of the thin-film transistor (TFT)-driven active matrix manufacturing processes, which can exceed $623 \mathrm{~K}$ for liquid crystal display (LCD), or active matrix organic light-emitting display (AMOLED) devices. Most common optical polymer films, such as poly(ethylene 
terephthalate) (PET, $T_{\mathrm{g}} \sim 351 \mathrm{~K}$ ), poly(ethylene naphthalate) (PEN, $T_{\mathrm{g}} \sim 396 \mathrm{~K}$ ), polycarbonate (PC, $T_{\mathrm{g}} \sim 423 \mathrm{~K}$ ), and polyethersulfone (PES, $T_{\mathrm{g}} \sim 496 \mathrm{~K}$ ) have limited service temperatures, and lose their optical transmittance, or deteriorate mechanically at such high manufacturing temperatures $[5,6]$. Temperature-resistant optical polymers therefore represent an interesting and promising class of materials because they are potential alternatives to traditional glass substrates in optoelectronic applications, with potentially better performance and durability.

Among possible candidates, wholly aromatic polyimides (PIs) have outstanding thermal stability $\left(T_{\mathrm{g}}>523 \mathrm{~K}\right)$, are mechanically tough, and exhibit high solvent resistance and good electrical properties [7-12]. However, they have dark colors (pale yellow to brown) and poor optical transparency in optoelectronic applications $[13,14]$. In the aromatic PIs, this coloration and the characteristic absorption in the visible region originate from intra- and intermolecular charge transfer (CT) between the electron-accepting dianhydride and the electron-donating diamine moiety [15]. In addition, the high chain-packing order at the nanometer level of the PI degrades its optical properties due to Rayleigh scattering. Various approaches were developed to inhibit the CT interactions of conventional aromatic PIs for optoelectronic device applications, including the use of cycloaliphatic moieties, bulky pendant groups, electron-rich bridges (such as -O-), electron-withdrawing groups, and asymmetrical structures in their backbones [16-19]. However, these methods generally result in poor thermal and mechanical properties. Achieving a compromise between a light color and a high thermal stability is, therefore, a significant challenge in the development of optoelectronic polymeric substrates.

Recently, Hasegawa et al. reported various methyl- or alkyl-substituted poly(ester imide) (PEsI) systems to form colorless heat-resistant polymers [20,21]. They discussed the effect of substituents (various numbers and positions) in the ester-linked tetracarboxylic dianhydrides on the optical and thermal properties, and suggested appropriate copolymer combinations. Quite recently, we developed new aromatic PEsIs using an ester-bridged aromatic diamine with dimethyl groups at the ortho-position of the amino groups [22]. Although this PI has one of the lowest coefficients of thermal expansion (CTE) among aromatic PIs, by controlling the dihedral torsion angle between the dimethyl-substituted phenylene ring and the imide ring, it still has coloration. Thus, we continued efforts to develop PIs with high transparency, as well as high $T_{\mathrm{g}}$ and low CTE values, based on the highly twisted conformations of the phenylimides.

At the beginning phase in the development of a new optical PI polymer, it is generally necessary to investigate how numerous functional groups influence the characteristics of the PIs. This type of synthesis involves long cycles, and limitations imposed by experimental conditions. As a result, it is undesirable and expensive to attempt the synthesis of all possible PI structures without a suitable methodology of increasing the potential for success. For this reason, the ability to predict the characteristics of polymer materials from their chemical constitution is particularly important for the selection and design of new high-performance materials. Computer-aided modeling consequently became a standard method for studying complex polymer systems, and has now widely used to predict the physical properties of polymer materials. The modeling is useful for the suggestion of potential materials with predefined characteristics. For example, molecular dynamics (MD) simulation is a well-known way of studying bulk polymers at the molecular level [23,24]. In particular, it allows thermodynamic behavior, such as the glass-transition temperature $\left(T_{\mathrm{g}}\right)$ and the coefficient of thermal expansion (CTE) of a candidate polymer, to be studied effectively [25-28].

Herein, we described a strategic approach to the design of transparent, high-temperature-resistant polyimides. The model compounds for the PEsIs were newly designed using different molecular structures of ester-bridged aromatic diamines, mainly bis-(4-amino-3-trifluoromethyl-phenyl) terephthalate (BATFMT), bis-(4-amino-3,5-bis-trifluoromethyl-phenyl) terephthalate (BABTFMT), and bis-(4-amino-2,3,5-tris-trifluoromethyl-phenyl) terephthalate (BATTFMT). Computer simulations were performed to predict the optical and thermomechanical properties of the PEsI model compounds. We firstly employed density functional theory (DFT) calculations to interpret the coloration of the model molecules. Details of the MD simulation were described in order to obtain insight into the 
molecular structure and thermal properties of the PEsIs. We obtained comparative values of the $T_{\mathrm{g}}$ and CTE of various PEsIs samples, and analyzed the role of various potential energy components in the glass-transition process. The torsion angle distributions of the PEsI chains at various temperatures were discussed to explain the chain conformations before and after the glass transition.

\section{Methodology}

\subsection{Molecular Design}

The chemical structures of the repeat units and the three-dimensional (3D) molecular structures of the model compounds for the seven PEsI models used in this study are shown in Figure 1. The seven PEsIs were synthesized from 3,3',4,4'-biphenyltetracarboxylic dianhydride (BPDA) and corresponding diamines (i.e., bis-(4-amino-phenyl) terephthalate (BAT), bis-(4-amino-3-methylphenyl) terephthalate (BAMT), bis-(4-amino-3,5-dimethyl-phenyl) terephthalate (BADMT), bis-(4-amino-2,3,5,-trimethyl-phenyl) terephthalate (BATMT), bis-(4-amino-3-trifluoromethyl-phenyl) terephthalate (BATFMT), bis-(4-amino-3,5-bis-trifluoromethyl-phenyl) terephthalate (BABTFMT), and bis-(4-amino-2,3,5-tris-trifluoromethyl-phenyl) terephthalate (BATTFMT). For convenience, the PEsI models are denoted as PEsI- $\left(\mathrm{CH}_{3}\right)_{1}$ for BPDA-BAMT, PEsI- $\left(\mathrm{CH}_{3}\right)_{2}$ for BPDA-BADMT, PEsI- $\left(\mathrm{CH}_{3}\right)_{3}$ for BPDA-BATMT, PEsI- $\left(\mathrm{CF}_{3}\right)_{1}$ for BPDA-BATFMT, PEsI- $\left(\mathrm{CF}_{3}\right)_{2}$ for BPDA-BABTFMT, and PEsI- $\left(\mathrm{CF}_{3}\right)_{3}$ for BPDA-BATTFMT. To confirm the substituent effect, a controlled sample was prepared and labeled as PEsI-H (BPDA-BAT). To illustrate their respective possibilities, a series of PEsI- $(\mathrm{CF})_{\mathrm{x}}$ models, which were not yet synthesized, but have great potential as next-generation transparent plastic substrates, was included in this study. The PEsI- $(\mathrm{CF})_{\mathrm{x}}$ series involves modifications of the corresponding PEsI- $\left(\mathrm{CH}_{3}\right)_{\mathrm{x}}$ counterparts instead of $-\mathrm{CH}_{3}$ groups per repeat unit. Each substituent was located at the ortho- and meta-positions of the amino groups.
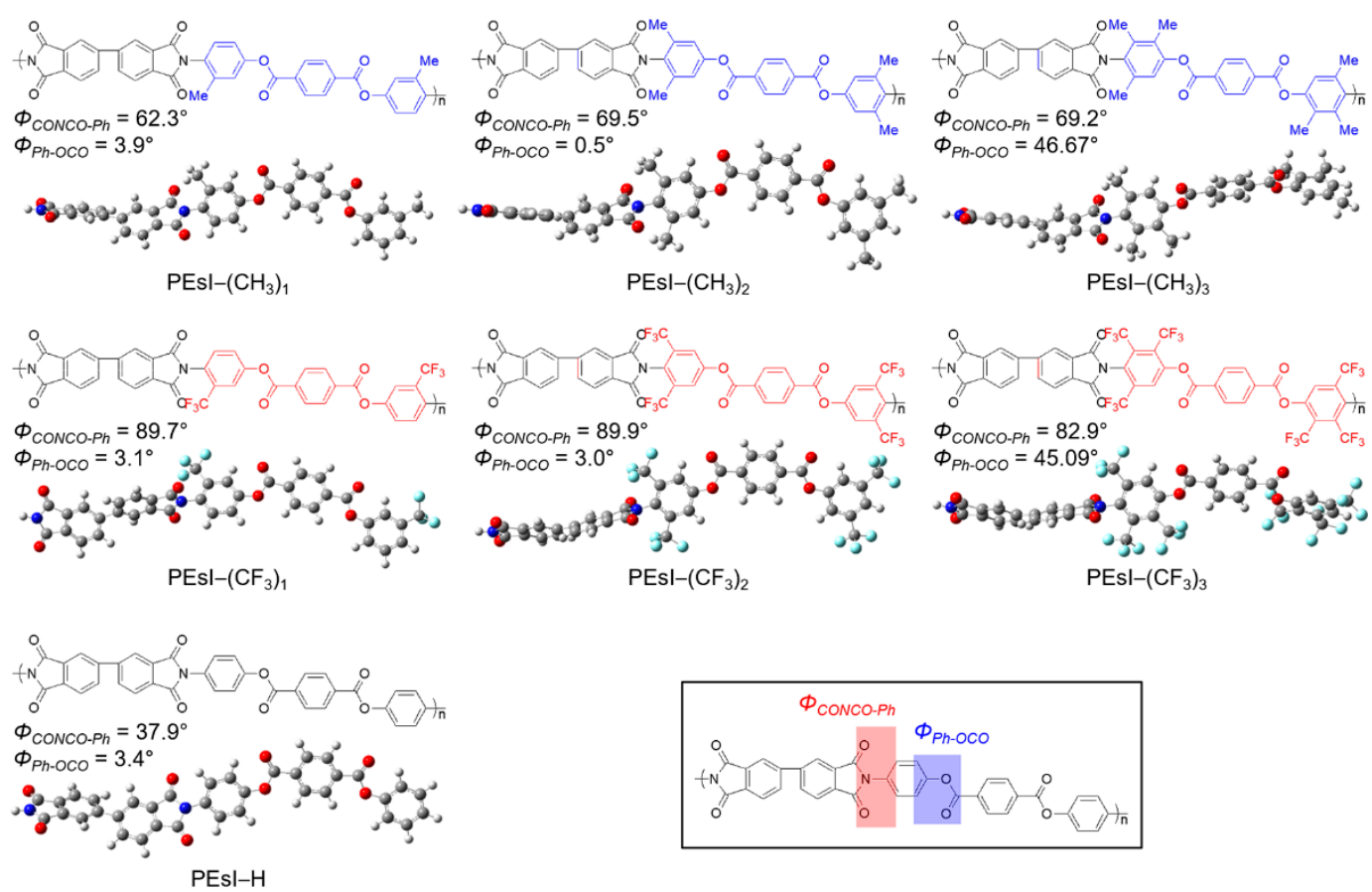

Figure 1. Chemical structures and three-dimensional (3D) molecular structures of the model compounds for the poly(ester imide) (PEsI) systems. 


\subsection{Simulation Protocol}

MD simulations were performed with the Materials Studio software. In the simulations, a COMPASS II force field, including a coupling-effect energy term, was used to consider complex chain relationships in an amorphous polymer. The total potential energy equation is expressed as follows [29,30]:

$$
\begin{aligned}
U_{\text {total }} & =\sum_{\text {stretch }}\left[k_{2}\left(b-b_{0}\right)^{2}+k_{3}\left(b-b_{0}\right)^{3}+k_{4}\left(b-b_{0}\right)^{4}\right] \\
& +\sum_{\text {angle }}\left[k_{2}\left(\theta-\theta_{0}\right)^{2}+k_{3}\left(\theta-\theta_{0}\right)^{3}+k_{4}\left(\theta-\theta_{0}\right)^{4}\right] \\
& +\sum_{\text {bending }}\left[k_{1}(1-\cos \phi)+k_{2}(1-2 \cos \phi)+k_{3}(1-\cos 3 \phi)\right]+\sum_{\text {torsion }} k_{2}\left(\chi-\chi_{0}\right)^{2} \\
& +\sum_{\text {vdW }} k_{5}\left[2\left(\frac{r_{i j}^{0}}{r_{i j}}\right)^{9}-3\left(\frac{r_{i j}^{0}}{r_{i j}}\right)^{6}\right]+\sum_{\text {electro }} \frac{q_{i} q_{j}}{r_{i j}} \\
& +\sum_{s, s^{\prime}} k_{6}\left(b-b_{0}\right)\left(b^{\prime}-b^{\prime}{ }_{0}\right)+\sum_{s, a} k_{6}\left(b-b_{0}\right)\left(\theta-\theta_{0}\right) \\
& +\sum_{s, b} k_{6}\left(b-b_{0}\right)(1-\cos \phi)+\sum_{a, a^{\prime}} k_{6}\left(\theta-\theta_{0}\right)\left(\theta^{\prime}-\theta^{\prime}{ }_{0}\right)
\end{aligned}
$$

where $U_{\text {total }}$ is the total potential energy including bond balance, non-bonding, and coupling energy terms. This equation is widely used to calculate the potential energy of complex structures such as amorphous polymers. $b$ is the chemical bond length, $\theta$ is the angle variation, $\phi$ is the bending angle, $\chi$ is the torsion angle, $r$ is the distance between $i$ th and $j$ th atoms, and $q_{i}$ is the quantity of electric charge of $i$ th atom. $k_{1}, k_{2}, k_{3}, k_{4}, k_{5}$, and $k_{6}$ are the force-field constants for the corresponding energy terms, and they are determined based on the type of interactive atoms. A subscript 0 indicates the value of the initial state. The cut-off distance for a non-bonding interaction was $1.50 \mathrm{~nm}$.

\subsection{Details of $M D$ Calculations}

The PEsI chains were modeled as a unit chain $(n=1)$ to verify the interactions between the chains. The simulation cells were configured with a periodic boundary of $4.0 \mathrm{~nm} \times 4.0 \mathrm{~nm} \times 4.0 \mathrm{~nm}$, as shown in Figure 2. The cells were packed with the PEsI unit chains with a density of $1.4 \mathrm{~g} \cdot \mathrm{cm}^{-3}$ (the density of BAT). Energy minimization of the cells was performed using a smart algorithm for the geometric optimization of the chains, and its tolerance was $10^{-8} \mathrm{kcal} \cdot \mathrm{mol}^{-1}$. The minimized models were stabilized in isothermal and isobaric conditions (NPT ensemble). The temperature and pressure were set to room temperature $(298 \mathrm{~K})$ and atmospheric pressure $(1 \mathrm{~atm})$, respectively. This process was performed with a time step of $1 \mathrm{fs}$ until the density of the simulation cell satisfied the tolerance of $10^{-3} \mathrm{~g} \cdot \mathrm{cm}^{-3}$. The average time for equilibration was about $1 \mathrm{~ns}$.

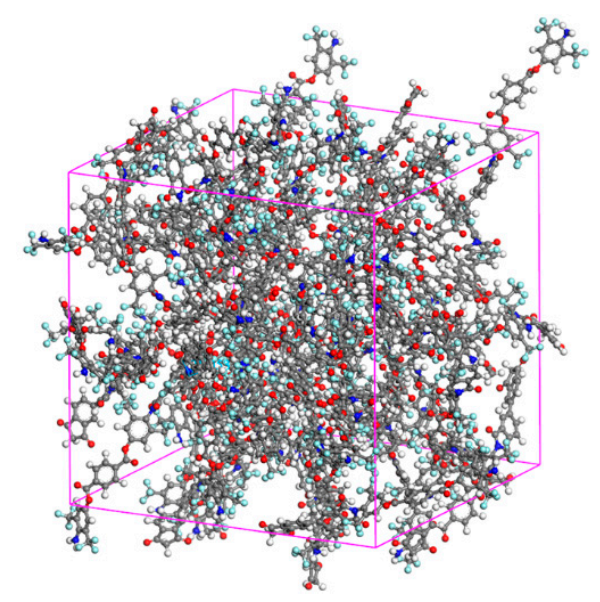

Figure 2. Randomly packed model compounds for PEsI- $\left(\mathrm{CF}_{3}\right)_{1}$ in a 3D periodic boundary cell. 
The cooling-down simulations were performed to predict the relationship between the temperature and density of the simulation cell. The inner temperature of the cells was reduced from 1000 to $300 \mathrm{~K}$ in steps of $50 \mathrm{~K}$. The NPT ensemble was performed for $500 \mathrm{ps}$ at each temperature. The density for each temperature was calculated to plot the dimension change with respect to temperature. The $T_{\mathrm{g}}$ and CTE were determined from the slope and the cross point of the data fitting curves [31]. In addition, the mean-square displacements, potential energies, and torsion angle distributions of the $\mathrm{C}-\mathrm{N}$ imide bonds of PEsI models were calculated to explain the influence of the substituents on the thermo-chemical characteristics of the PEsI system.

\section{Results and Discussion}

\subsection{Molecular Orbital Calculation}

In order to gain insight into the coloration of the PEsIs, the software package Gaussian 09 was used for the DFT calculation [32]. Figure S1 shows a theoretical calculation of the three-dimensional (3D) molecular structures of the PEsIs, and their molecular orbital (MO) diagrams. Figure 3 provides details of the quantum-chemical calculations, molecular orbital diagrams, and calculated electronic transitions of the model compounds for the three representative systems-PEsI- $\left(\mathrm{CF}_{3}\right)_{1}$, PEsI- $\left(\mathrm{CF}_{3}\right)_{2}$, and PEsI- $\left(\mathrm{CF}_{3}\right)_{3}$-at the optimized $S_{0}$ geometry. The model compounds were composed of the basic units of the polymers, and their electronic transitions were calculated using the Becke, three-parameter, Lee-Yang-Parr (B3LYP) level with the 6-31G basis set [32]. Irrespective of the nature of the tetracarboxylic dianhydride, the calculated dihedral angles of a series of PEsI- $\left(\mathrm{CF}_{3}\right)_{\mathrm{x}}$ between the $-\mathrm{CF}_{3}$-substituted phenylene ring and the imide ring at round states were in the range of 82.9-89.9 , which was significantly larger than the dihedral angles observed in the unsubstituted PEsI-H and $-\mathrm{CH}_{3}$-substituted PEsI- $\left(\mathrm{CH}_{3}\right)_{\mathrm{x}}$ system. Note that the steric hindrance, caused by the bulky $-\mathrm{CF}_{3}$ groups directly attached to the aromatic BAT, forced the imide bond to be almost perpendicular, thereby causing significant conformational distortion of the PEsI backbones. The greater dihedral angle of the PEsI- $\left(\mathrm{CF}_{3}\right)_{x}$ model was caused by the steric hindrance of the $-\mathrm{CF}_{3}$ groups, which reduced the close chain packing, resulting in a more colorless and transparent nature. Furthermore, the more twisted structure of the PEsI- $\left(\mathrm{CF}_{3}\right)_{\times}$model resulted in largely isolated electronic states of the molecular orbitals. The number of $-\mathrm{CF}_{3}$ groups had a greater influence on the optical properties than their positions in the PEsI backbone. The results showed that the judicious introduction of electron-withdrawing $-\mathrm{CF}_{3}$ groups to the diamine moiety of PEsIs, which had considerable steric hindrance on the backbone, was quite effective at eliminating or at least reducing the characteristic coloration of the aromatic PEsIs. 


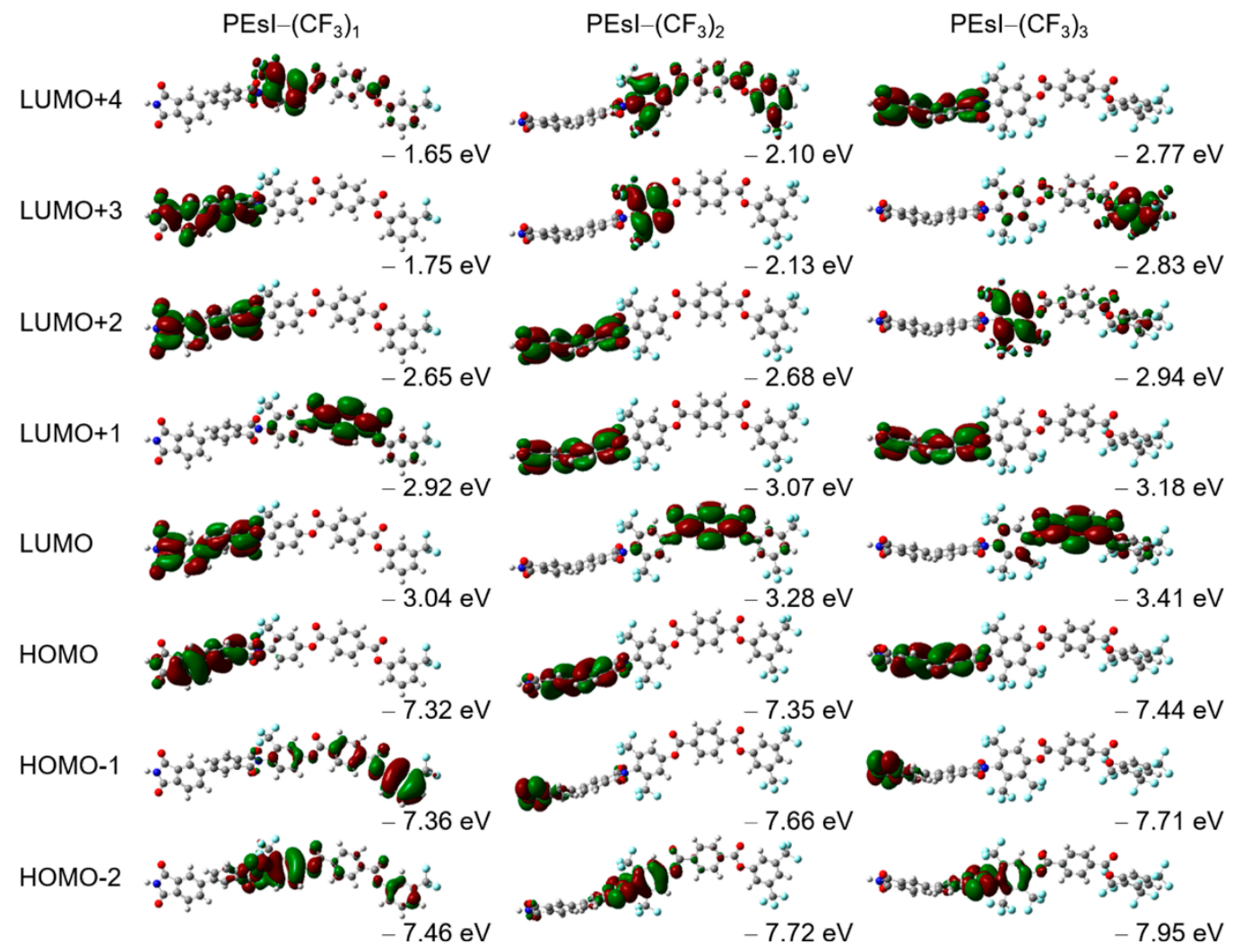

Figure 3. Calculated molecular orbitals and the corresponding energy levels of the repeating units of PEsI- $\left(\mathrm{CF}_{3}\right)_{\mathrm{x}}$ model compounds using the Becke, three-parameter, Lee-Yang-Parr (B3LYP) level with the 6-31G basis set (B3LYP/6-31G).

\subsection{Determination of the $T_{g}$ and CTE}

One of the most important parameters for the fabrication of the optical device is the $T_{\mathrm{g}}$. The temperature dependence of the dimension change of the PEsI models is shown in Figure 4. Dimension change means the linear change of cell length in the MD simulation. The dimension change exhibited a linear relationship with temperature at temperatures lower $\left(\alpha_{\text {glass }}\right.$, glassy region) or higher $\left(\alpha_{\text {rubber, }}\right.$, rubbery region) than the $T_{\mathrm{g}}$. Therefore, the $T_{\mathrm{g}}$ was determined by the point of intersection of the slopes corresponding to the heating and cooling processes. The $T_{\mathrm{g}} \mathrm{s}$ of the seven PEsIs were confirmed from the plots of dimension changes, obtained from the NPT dynamics versus temperature, for temperatures ranging below and above $T_{\mathrm{g}}$. The $T_{\mathrm{g}}$ values of the PEsI- $\left(\mathrm{CH}_{3}\right)_{\mathrm{x}}$ series ranged from 702 to $737 \mathrm{~K}$, and the PEsI- $\left(\mathrm{CF}_{3}\right)_{\mathrm{X}}$ series ranged from 697 to $731 \mathrm{~K}$, much higher than that of the PEsI-H's $(677 \mathrm{~K})$. It was found that the $T_{\mathrm{g}}$ values of the PEsIs were related to the structural effects of the aromatic diamines. The PEsIs having a $-\mathrm{CH}_{3}$ substituent exhibited a higher $T_{\mathrm{g}}$ in the order of PEsI- $\left(\mathrm{CH}_{3}\right)_{3}>$ PEsI- $\left(\mathrm{CH}_{3}\right)_{2}>$ PEsI- $\left(\mathrm{CH}_{3}\right)_{1}$. The results showed that the incorporation of $-\mathrm{CH}_{3}$ groups at the ortho- and meta-positions of the amino groups effectively increased $T_{\mathrm{g}}$ values, by increasing the chain rigidity of the PEsI; that is, the $-\mathrm{CH}_{3}$ groups significantly constrained bond rotation around the $\mathrm{C}-\mathrm{N}$ imide bonds. The PEsI model was quite effective at increasing the $T_{\mathrm{g}}$ when the $-\mathrm{CF}_{3}$ substitution was introduced at the 3-position of the 4-aminophenyl moiety. This was supported by the fact that the highly twisted dihedral angles of the $\mathrm{C}-\mathrm{N}$ imide bonds in the optimized geometry (Figure 1) of the models were $89.7^{\circ}, 89.9^{\circ}$, and $82.9^{\circ}$ for PEsI- $\left(\mathrm{CF}_{3}\right)_{1}, \mathrm{PEsI}-\left(\mathrm{CF}_{3}\right)_{2}$, and PEsI- $\left(\mathrm{CF}_{3}\right)_{3}$, respectively. The bulkier $-\mathrm{CF}_{3}$ substitution stiffened the polymer main chain more effectively than the $-\mathrm{CH}_{3}$ unit by introducing a barrier to segmental rotation. Despite the significant increase in $T_{\mathrm{g}}$ in PEsI- $\left(\mathrm{CF}_{3}\right)_{1}$ when compared with its analogous counterpart $\left(\mathrm{PEsI}-\left(\mathrm{CH}_{3}\right)_{1}\right)$, the $T_{\mathrm{g}}$ values in PEsI- $\left(\mathrm{CF}_{3}\right)_{2}$ and PEsI- $\left(\mathrm{CF}_{3}\right)_{3}$ were found to be slightly reduced. This could be explained by the disturbed inter-chain 
interactions from the high free volume present in PEsI- $\left(\mathrm{CF}_{3}\right)_{\mathrm{x}}$, owing to their bulky $-\mathrm{CF}_{3}$ moieties and non-coplanar structure.
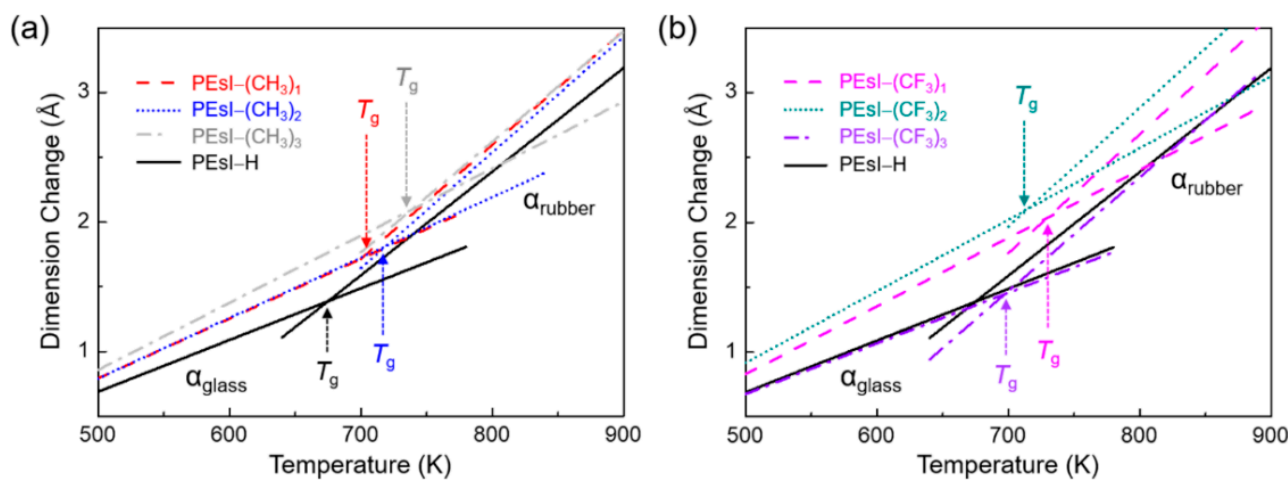

Figure 4. Plots of dimension change versus temperature obtained from molecular dynamics (MD) simulations. (a) $-\mathrm{CH}_{3}$ - and (b) $-\mathrm{CF}_{3}$-substituted PEsI systems.

The CTE was determined to be the proper parameter for the estimation of the agreement between the theoretical results and experimental data because accurately determining $T_{\mathrm{g}}$ using MD simulations is rather complicated. The CTE was established using the relationship of temperature change and deformation. The dimension change with respect to temperature was obtained during the abovementioned cooling-down simulations. The CTE $(\alpha)$ was expressed as follows:

$$
\alpha=\frac{S}{\Delta T} \varepsilon_{T}=\frac{S}{\Delta T}\left(\frac{L}{L_{0}}-1\right)=\frac{S}{\Delta T}\left(\frac{\sqrt[3]{V}}{\sqrt[3]{V_{0}}}-1\right),
$$

where $\alpha$ is the linear thermal expansion coefficient, $L$ and $V$ are the length and volume of the simulation cell, respectively, $\Delta T$ is temperature change, and subscript 0 indicates the initial state. $S$ is a scale factor $\left(=10^{-6}\right)$ to convert the units of CTE to ppm. The CTE was calculated from the slope of the curve of dimension change versus temperature, and the initial simulation-cell length.

Table 1 shows the calculated CTEs for the PEsIs in the glassy and rubbery states compared with the experimental values available from our previous work. It can be seen that the computed values for the CTEs of the PEsI-H and PEsI- $\left(\mathrm{CH}_{3}\right)_{2}$ were in very good agreement with the experimental data (Figure S2). All of the pseudo rigid-rod-like structures of the BPDA-based PEsI model molecules had low CTE values of less than $14 \mathrm{ppm} \cdot \mathrm{K}^{-1}$ in the MD calculations. Considering that the CTE of current glass substrates is $5-9 \mathrm{ppm} \cdot \mathrm{K}^{-1}$ [33], the CTE values of the PEsIs were within the effective range for applications as a plastic substrate. Interestingly, despite the bulky $-\mathrm{CF}_{3}$ groups interfering with chain packing, the PEsI- $\left(\mathrm{CF}_{3}\right)_{x}$ series showed a low level of CTEs similar to the PEsI- $\left(\mathrm{CH}_{3}\right)_{\mathrm{x}}$ series. This suggested that the considerably distorted conformations in the PEsI systems effectively constrained the degree of rotational freedom at the $\mathrm{C}-\mathrm{N}$ imide bonds, leading to the strong chain stiffness of the macromolecules. The steric effect was more noticeable for the PEsI- $\left(\mathrm{CF}_{3}\right)_{3}$ because they had two different types of steric hindrance: between the imide ring and the benzene ring, and between the two benzene rings of the diamine along the ester-linkage axis. Therefore, the consecutive rigid rings along the main chains in the PEsI- $\left(\mathrm{CF}_{3}\right)_{3}$ had significantly distorted conformations. These results provided valuable information about the thermal properties of the newly designed polymers, which were previously limited to empirical measurements. 
Table 1. Glass-transition temperature $\left(T_{\mathrm{g}}\right)$ and thermal expansion coefficients $(\alpha)$ of the seven poly(ester imide) (PEsI) models.

\begin{tabular}{cccccc}
\hline Sample code & $\boldsymbol{T}_{\mathbf{g}}$ exp $(\mathbf{K})$ & $\boldsymbol{T}_{\mathbf{g}}(\mathbf{K})$ & $\boldsymbol{\alpha}^{\mathbf{e x p}} \mathbf{( \mathbf { p p m } \cdot \mathbf { K } ^ { - \mathbf { 1 } } )}$ & $\boldsymbol{\alpha}^{\text {glassy }} \mathbf{( \mathbf { p p m } \cdot \mathbf { K } ^ { - \mathbf { 1 } } )}$ & $\boldsymbol{\alpha}^{\text {rubbery }}\left(\mathbf{p p m} \cdot \mathbf{K}^{-\mathbf{1}}\right)$ \\
\hline PEsI- $\left(\mathrm{CH}_{3}\right)_{1}$ & - & 701.5 & NA & 11.2 & 21.4 \\
PEsI- $\left(\mathrm{CH}_{3}\right)_{2}$ & $>623$ & 720.8 & 11.3 & 11.3 & 21.7 \\
PEsI- $\left(\mathrm{CH}_{3}\right)_{3}$ & - & 737.4 & - & 12.6 & 20.8 \\
PEsI- $\left(\mathrm{CF}_{3}\right)_{1}$ & - & 730.9 & - & 12.8 & 22.3 \\
PEsI- $\left(\mathrm{CF}_{3}\right)_{2}$ & - & 714.9 & - & 13.4 & 22.3 \\
PEsI- $\left(\mathrm{CF}_{3}\right)_{3}$ & - & 696.9 & - & 9.5 & 21.3 \\
PEsI-H & $>623$ & 676.9 & 8.2 & 9.7 & 19.5 \\
\hline
\end{tabular}

The data of experimental $T_{\mathrm{g}}$ (PEsI-Me $\mathrm{M}_{2}$ and PEsI-H) cited in this table were investigated using dynamic mechanical thermal analysis (DMA) at a heating rate of $3{ }^{\circ} \mathrm{C} \cdot \mathrm{min}^{-1}$ with a load frequency of $1 \mathrm{~Hz}$ in air, and were reproduced from Reference [22] with permission from ELSEVIER, Copyright 2017.

\subsection{Mean-Square Displacement}

$T_{\mathrm{g}}$ was well correlated with the rigidity of the polymer, specifically the segmental motion in the polymer chain. To observe the mobility of the PEsI chains during the glassy to rubbery phase transition, the mean-square displacements (MSDs) of the PEsI molecular systems were calculated [31]. The MSD of $N$ atoms is expressed as follows:

$$
\operatorname{MSD}=\frac{1}{3 N} \sum_{i=0}^{N-1}\left\langle\left|\vec{R}_{i}(t)-\vec{R}_{i}(0)\right|^{2}\right\rangle
$$

where $R_{i}(t)$ indicates the position vector of the $i$ th atom at time $t$ [34]. The MSD curves for each temperature were obtained from the values of the initial 50 ps of each NPT ensemble. The relative dispersion of polymer chains was estimated from the variation in the MSD curve with temperature. When the temperature of the simulation cell reached $T_{\mathrm{g}}$, its relative dispersion suddenly increased. Thus, the temperature ranges between the points where the MSD curves suddenly increased were candidates for the glass-transition region. The glassy and rubbery regions were classified using these temperature ranges, and each region had independent characteristics. Therefore, by investigating the interval between each MSD curve, an approximate candidate range for the $T_{\mathrm{g}}$ was estimated within $50 \mathrm{~K}$.

As shown in Figure S3, the motion of the chain segment of the PEsI systems increased consistently with the increasing temperature. As an example, using PEsI- $\left(\mathrm{CH}_{3}\right)_{1}$ and PEsI- $\left(\mathrm{CF}_{3}\right)_{1}$, the MSD plots for the two PEsI systems at 400 and $850 \mathrm{~K}$ are illustrated in Figure 5a. It shows that the MSD variation between 400 and $800 \mathrm{~K}$ for the PEsI- $\left(\mathrm{CF}_{3}\right)_{1}$ system was lower than that for the PEsI- $\left(\mathrm{CH}_{3}\right)_{1}$ system's all-time range. The bulky $-\mathrm{CF}_{3}$ groups were generally believed to form a loosely packed PI structure, but their bulky structure effectively induced a highly twisted form in phenylimide due to the structural steric effect of the substituents. This caused the ortho $-\mathrm{CF}_{3}$ substituent of PEsI- $\left(\mathrm{CF}_{3}\right)_{1}$ to stiffen the polymer main chain more effectively, by providing a barrier to segmental rotation. Hence, it needed more time to produce the segmental motion of PEsI- $\left(\mathrm{CH}_{3}\right)_{1}$ than its counterparts. The slope of the MSD above the $T_{\mathrm{g}}$ value was much higher than that below $T_{\mathrm{g}}$, indicating that each of the PEsI chains had higher mobility above the glass-transition region. This abrupt change between the two temperature zones, based on the $T_{\mathrm{g}}$, can be seen more clearly in Figure $5 \mathrm{~b}$, where the MSD is plotted as a function of temperature at 50-ps time periods. The $T_{\mathrm{g}}$ of the PEsIs was also identified through the slope change of the MSD curve of the chain segments versus the temperature [35]. It can be seen that the $T_{\mathrm{g}} \mathrm{s}$ of all PEsI systems (Figure S4) were above $400 \mathrm{~K}$, and consistent with the results described in Section 3.2. 
(a)

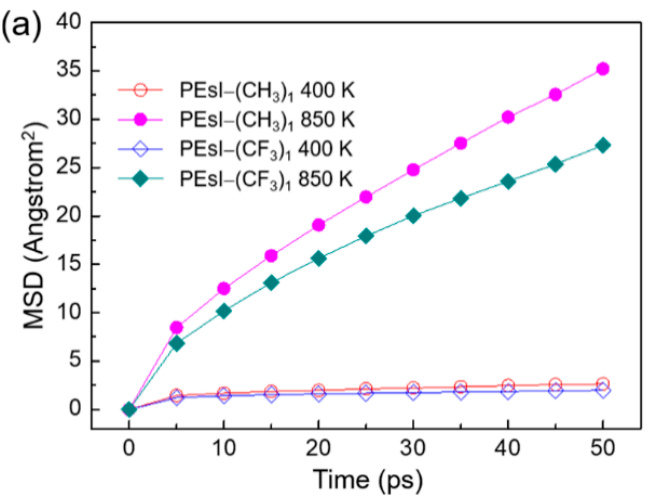

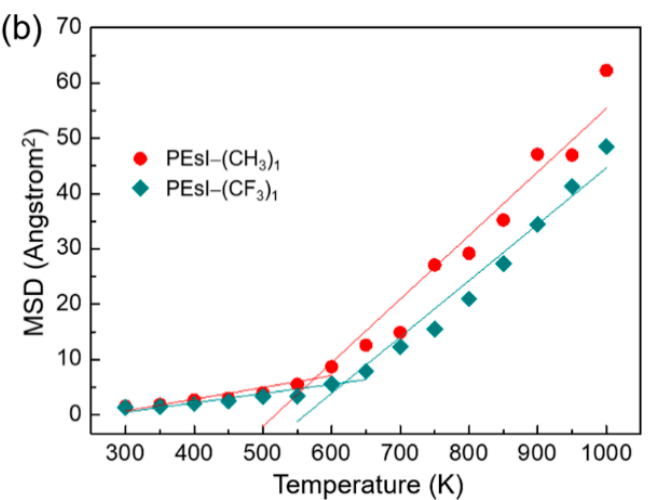

Figure 5. (a) Mean-square displacement (MSD) curves as a function of time for PEsI- $\left(\mathrm{CH}_{3}\right)_{1}$ and PEsI- $\left(\mathrm{CF}_{3}\right)_{1}$ at 400 and $850 \mathrm{~K}$. (b) MSD curves as a function of temperature at 50-ps time intervals for the unit cells of the PEsI- $\left(\mathrm{CH}_{3}\right)_{1}$ and PEsI- $\left(\mathrm{CF}_{3}\right)_{1}$ systems.

\subsection{Role of the Energy Components}

Various interaction-energy components were also used to investigate the glass transition occurring in the PEsIs [36-38]. The calculated results of bond stretching energy $\left(E_{\text {bond }}\right)$, angle variation energy $\left(E_{\text {angle }}\right)$, dihedral torsional energy $\left(E_{\text {torsion }}\right)$, and van der Waals energy $\left(E_{\mathrm{vdW}}\right)$ versus the temperature are plotted in Figure 6. In the $E_{\mathrm{vdW}}$ versus temperature plot, it can be seen that there was a break indicating where the glass transition occurred. In the regions both below $T_{\mathrm{g}}$ and above $T_{\mathrm{g}}, E_{\mathrm{vdW}}$ had a linear relationship with temperature, with a break at $T_{\mathrm{g}}$. However, the other potential energy components continued to increase linearly with increasing temperature without any break. These results indicated that the $E_{\mathrm{vdW}}$ played a crucial role in the glass-transition process of the PEsI systems.
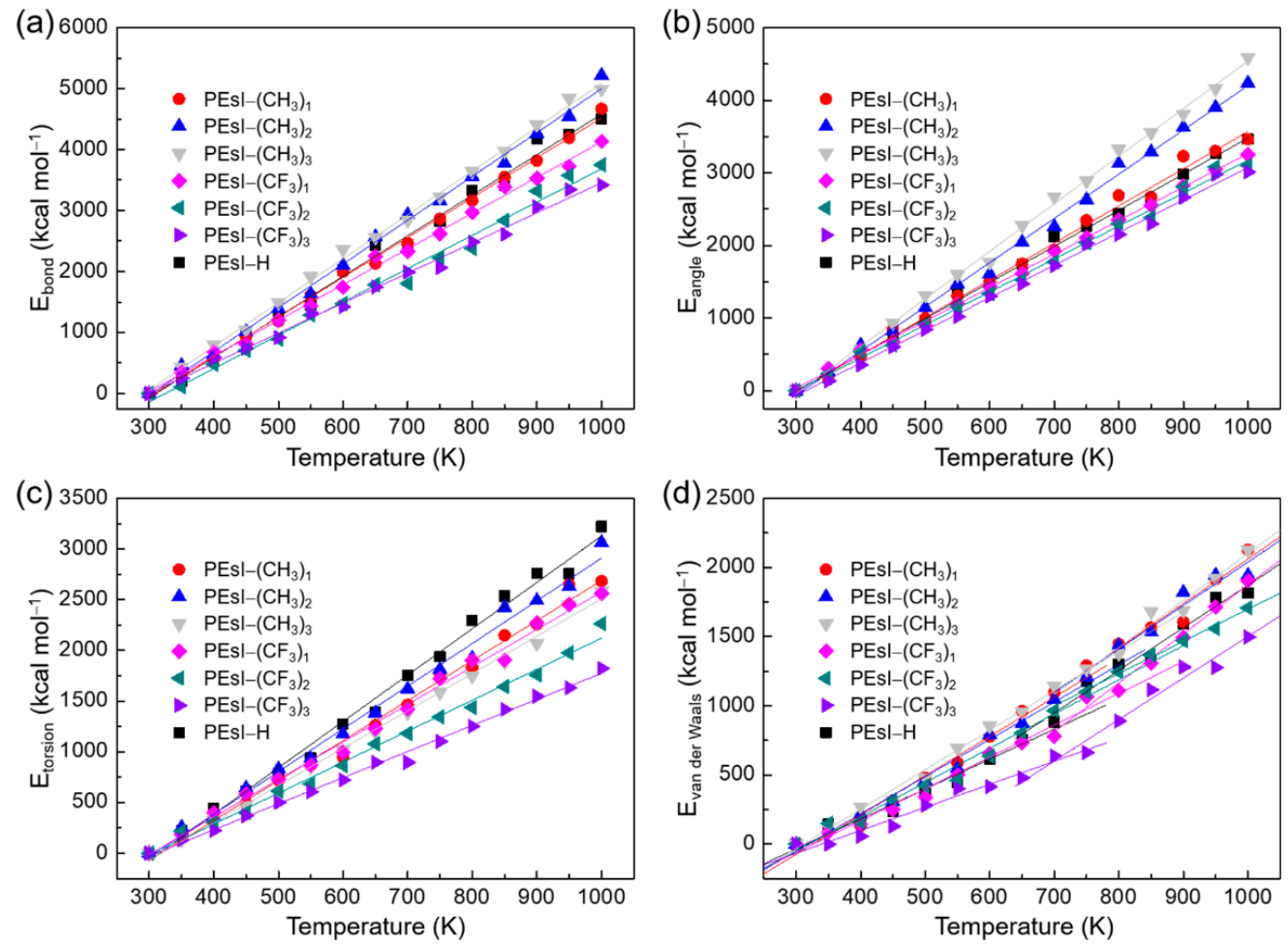

Figure 6. Plots of potential energy components versus temperature of the PEsI systems. (a) Bond stretching energy $\left(E_{\text {bond }}\right),(\mathbf{b})$ angle variation energy $\left(E_{\text {angle }}\right),(\mathbf{c})$ dihedral torsional energy $\left(E_{\text {torsion }}\right)$, and $(\mathbf{d})$ van der Waals energy $\left(E_{\mathrm{vdW}}\right)$. 


\subsection{Torsion Angle Distribution}

The mobility of the $\mathrm{C}-\mathrm{N}$ imide bonds, provided by the substituent patterns, exerted a significant influence on the glass-transition process. The investigated torsion $\left(\Phi_{\mathrm{CONCO}-\mathrm{Ph}}\right)$ along the chemical backbone of the substituted PEsIs was set from $-180^{\circ}$ to $+180^{\circ}$, and is defined in Figure 7 . The PEsIs had a different peak position and relative proportion for $\Phi_{\text {CONCO-Ph }}$ (the torsion angle between the imide and phenyl rings) depending on their molecular structures. PEsI-H (Figure S5) and PEsI- $\left(\mathrm{CH}_{3}\right)_{1}$ had many peaks over the range of $\pm 15^{\circ}$ to $\pm 165^{\circ}$, but there were only two major peaks located in the $\pm 90^{\circ}$ range in other PEsI systems. These were attributable to the ortho- and/or meta-substitution in the aromatic diamine compounds, which induced significant steric hindrance around the $\mathrm{C}-\mathrm{N}$ imide bonds. Notably, the steric hindrance between adjacent groups, derived from the 3-trifluoromethyl moiety, greatly restricted the torsional bond rotation of the $\mathrm{C}-\mathrm{N}$ imide bonds. Actually, the probability distribution of the torsion angle at $\Phi_{\mathrm{CONCO}-\mathrm{Ph}}$ with temperature was narrower in the PEsI- $\left(\mathrm{CF}_{3}\right)_{\mathrm{x}}$ series. This result was consistent with the torsion angles obtained in the molecular structures of the stabilized model compounds (Figure 1). To investigate the effect of temperature on torsion-angle distribution, the torsion-angle distributions of the PEsI series were obtained at 400 and $850 \mathrm{~K}$. These distribution functions showed peaks at the same position for the two temperatures, and had a wider distribution at higher temperatures; however, they showed a slight difference in probability densities. Regardless of the glassy or rubbery state, the torsion angle of the PEsIs, excluding PEsI-H and PEsI- $\left(\mathrm{CH}_{3}\right)_{1}$, remained at approximately $\pm 90^{\circ}$. This proved that the $E_{\text {torsion }}$ was not abruptly changed by the glass-transition process, due to the limited torsion discussed in Section 3.3. In conclusion, $T_{\mathrm{g}}$ was found to correlate with the rotation-barrier height of the imide bond.

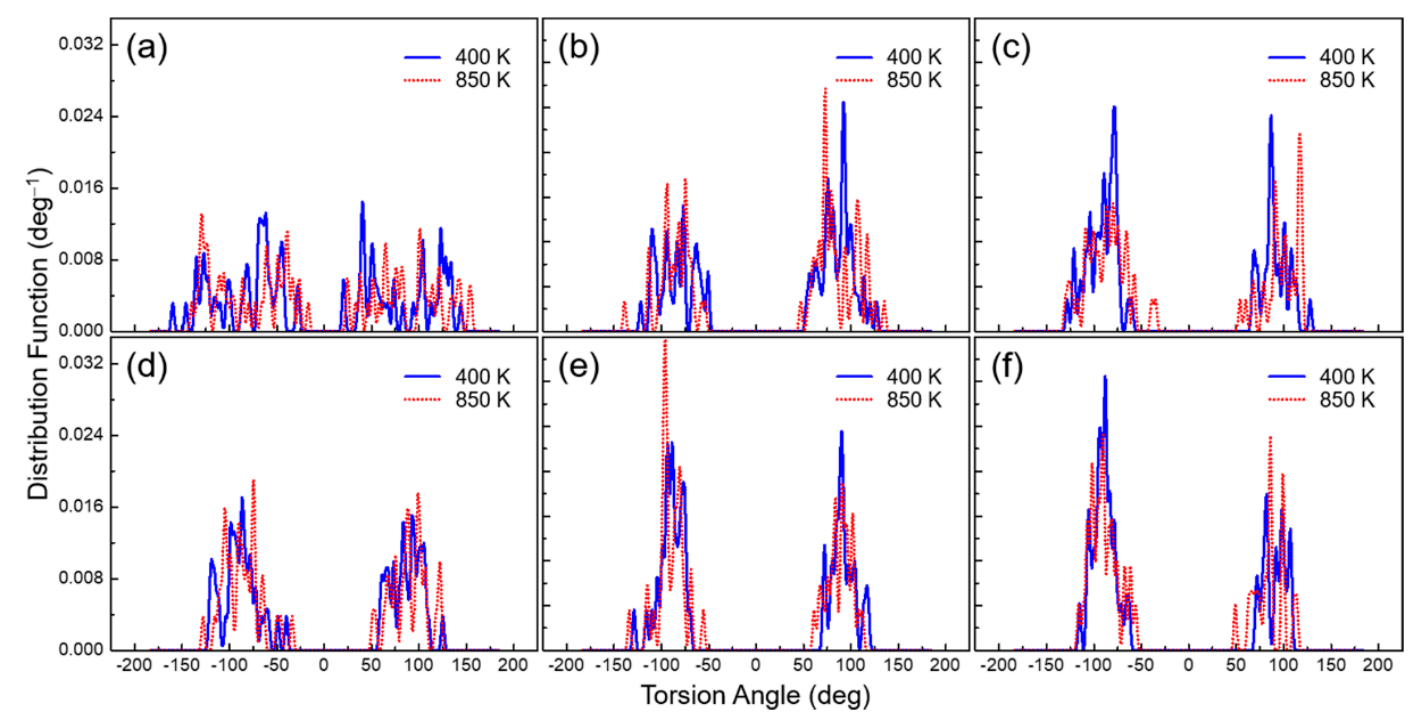

Figure 7. Torsion angle distributions of the PEsI systems obtained from the MD simulations at 400 and $850 \mathrm{~K}$. (a) PEsI- $\left(\mathrm{CH}_{3}\right)_{1} ;$ (b) PEsI- $\left(\mathrm{CH}_{3}\right)_{2} ;$ (c) PEsI- $\left(\mathrm{CH}_{3}\right)_{3} ;$ (d) PEsI- $\left(\mathrm{CF}_{3}\right)_{1} ;$ (e) PEsI- $\left(\mathrm{CF}_{3}\right)_{2}$; and (f) PEsI- $\left(\mathrm{CF}_{3}\right)_{3}$.

Table S1 shows a final comparison of the $T_{\mathrm{g}}$ and CTE values of PEsI- $\left(\mathrm{CF}_{3}\right)_{1}$ with fluorinated PIs, taken from previous work in the literature. From these data, it became clear that the current methodology of formation of the highly distorted conformation at the $\mathrm{C}-\mathrm{N}$ imide bonds resulted in high-temperature-resistant $\left(T_{\mathrm{g}}>731 \mathrm{~K}\right)$ and highly transparent optical polymers. We also believed that the introduction of a small number of $-\mathrm{CF}_{3}$ groups at only the ortho-positions of the amino groups could potentially reduce the production cost of fluorinated PIs, for applications in the optoelectronic field. 


\section{Conclusions}

In this study, we designed seven polymer models that have the potential of being future optical polymer films, and computed their thermomechanical and optical properties. The thermal behavior of the PEsIs was investigated using various MD calculations. The $T_{\mathrm{g}}$ of polymeric materials was mainly determined by the chain rigidity (time scale) and the strength of the inter-chain interactions (space scale). The theoretically found $T_{\mathrm{g}} \mathrm{s}$ of the PEsI systems consistently reproduced the chemical structure-property relationships in polymer backbone chain rigidity, and the substituent effects on the glass-transition process. Potential energy components, such as $E_{\mathrm{vdW}}$ and $E_{\mathrm{torsion}}$, played significant roles in the glass-transition behavior of the PEsIs, as shown by the plots of the energy components against temperatures ranging from below $T_{\mathrm{g}}$ to above $T_{\mathrm{g}}$. The $-\mathrm{CF}_{3}$ substituent in the PEsI backbone structure reduced the intra- and intermolecular charge-transfer complexes, keeping their rigid-rod-like backbones intact. It is very inspiring that, by applying MD simulations and DFT calculations, we found a new polymer model (PEsI- $\left.\left(\mathrm{CF}_{3}\right)_{1}\right)$ that satisfied both high optical and thermomechanical properties. This work provides a useful approach to the design of transparent, highly temperature-resistant molecular systems for advanced optical applications, when compared with the present fluorine chemistry of PIs.

Supplementary Materials: The following are available online at http:/ /www.mdpi.com/2073-4360/10/6/630/s1: Figure S1: Calculated molecular orbitals and the corresponding energy levels of the basic units of PEsI-H and PEsI- $\left(\mathrm{CH}_{3}\right)_{x}$ model compounds (B3LYP/6-31G); Figure S2: DMA thermograms of the PEsI-H and PEsI- $\left(\mathrm{CH}_{3}\right)_{2}$ films $\left(1 \mathrm{~Hz}, 3^{\circ} \mathrm{C} \cdot \mathrm{min}^{-1}\right)$, (a) storage modulus and (b) $\tan \delta$; Figure S3: MSD of the structures as a function of time for the PEsI systems, (a) PEI-(CH$)_{1}$, (b) PEI- $\left(\mathrm{CH}_{3}\right)_{2}$, (c) PEI- $\left(\mathrm{CH}_{3}\right)_{3}$, (d) PEI- $\left(\mathrm{CF}_{3}\right)_{1}$, (e) PEI- $\left(\mathrm{CF}_{3}\right)_{2}$, and (f) PEI- $\left(\mathrm{CF}_{3}\right)_{3}$; Figure S4: MSD curves as a function of temperature at 50-ps time intervals for the unit cells of PEsI systems; Figure S5: Torsion angle distributions of the PEsI-H systems derived from NVT MD simulations at 400 and $850 \mathrm{~K}$; and Table S1: Thermal properties of fluorinated PIs.

Author Contributions: K.-H.N. and B.-C.K. conceived the presented idea. H.K.C. and J.Y. conceived and designed the simulations. H.Y. and N.-H.Y. developed the polymer model, and performed the DFT calculations. H.K.C. and J.Y. performed the MD simulations. K.-H.N., H.K.C., and H.Y. analyzed the data, and wrote the manuscript. All authors have approved the final version of the manuscript.

Acknowledgments: This work was supported by a grant from the Korea Institute of Science and Technology (KIST) Institutional Program and the Space Core Technology Development Program through the National Research Foundation of Korea funded by the Ministry of Science and ICT (NRF-2017M1A3A3A02016310).

Conflicts of Interest: The authors declare no conflict of interest.

\section{References}

1. MacDonald, W.A. Engineered films for display technologies. J. Mater. Chem. 2004, 14, 4-10. [CrossRef]

2. Lee, S.J.; Ko, J.; Nam, K.-H.; Kim, T.; Lee, S.H.; Kim, J.H.; Chae, G.S.; Han, H.; Kim, Y.S.; Myoung, J.-M. Fully solution-processed and foldable metal-oxide thin-film transistor. ACS Appl. Mater. Interfaces 2016, 8, 12894-12900. [CrossRef] [PubMed]

3. Choi, M.-C.; Kim, Y.; Ha, C.-S. Polymers for flexible displays: From material selection to device applications. Prog. Polym. Sci. 2008, 33, 581-630. [CrossRef]

4. Logothetidis, S. Flexible organic electronic devices: Materials, process and applications. Mater. Sci. Eng. B-Adv. 2008, 152, 96-104. [CrossRef]

5. Hasegawa, M.; Hirano, D.; Fujii, M.; Haga, M.; Takezawa, E.; Yamaguchi, S.; Kshikawa, A.; Kagayama, T. Solution-processable colorless polyimides derived from hydrogenated pyromellitic dianhydride with controlled steric structure. J. Polym. Sci. Pol. Chem. 2013, 51, 575-592. [CrossRef]

6. Ha, C.-S.; Choi, M.-C.; Wakita, J.; Ando, S. Highly transparent and refractive polyimides with controlled molecular structure by chlorine side groups. Macromolecules 2009, 42, 5112-5120.

7. Yen, H.-J.; Chen, C.-J.; Liou, G.-S. Flexible multi-colored electrochromic and volatile polymer memory devices derived from starburst triarylamine-based electroactive polyimide. Adv. Funct. Mater. 2013, 23, 5307-5316. [CrossRef] 
8. Lim, J.; Shin, D.G.; Yeo, H.; Goh, M.; Ku, B.-C.; Yang, C.-M.; Lee, D.S.; Hwang, J.-Y.; Park, B.; You, N.-H. The mechanical and electrical properties of carbon nanotube-grafted polyimide nanocomposites. J. Polym. Sci. Part B-Polym. Phys. 2014, 52, 906-966. [CrossRef]

9. Erhard, D.P.; Richter, F.; Bartz, C.B.A.; Schmidt, H.-W. Fluorinated aromatic polyimides as high-performance electret materials. Macromol. Rapid Commun. 2015, 36, 520-527. [CrossRef] [PubMed]

10. Nam, K.-H.; Yu, J.; You, N.-H.; Han, H.; Ku, B.-C. Synergistic toughening of polymer nanocomposites by hydrogen-bond assisted three-dimensional network of functionalized graphene oxide and carbon nanotubes. Compos. Sci. Technol. 2017, 149, 228-234. [CrossRef]

11. Lim, J.; Yeo, H.; Goh, M.; Ku, B.-C.; Kim, S.G.; Lee, H.S.; Park, B.; You, N.-H. Grafting of polyimide onto chemically-functionalized graphene nanosheets for mechanically-strong barrier membranes. Chem. Mater. 2015, 27, 2040-2047. [CrossRef]

12. Zhai, L.; Yang, S.; Fan, L. Preparation and characterization of highly transparent and colorless semi-aromatic polyimide films derived from alicyclic dianhydride and aromatic diamines. Polymer 2012, 53, 3529-3539. [CrossRef]

13. Banach, M.J.; Friend, R.H.; Sirringhaus, H. Influence of the molecular weight on the thermotropic alignment of thin liquid crystalline polyfluorene copolymer films. Macromolecules 2003, 36, 2838-2844. [CrossRef]

14. Kurosawa, T.; Higashihara, T.; Ueda, M. Polyimide memory: A pithy guideline for future applications. Polym. Chem. 2013, 4, 16-30. [CrossRef]

15. Takasaki, T.; Kuwana, Y.; Takahashi, T.; Hayashida, S. Synthesis and optical properties of polyimides. J. Polym. Sci. Pol. Chem. 2000, 38, 4832-4838. [CrossRef]

16. Guan, Y.; Wang, C.; Wang, D.; Dang, G.; Chen, C.; Zhou, H.; Zhao, X. High transparent polyimides containing pyridine and biphenyl units: Synthesis, thermal, mechanical, crystal and optical properties. Polymer 2015, 62, 1-10. [CrossRef]

17. Rusanov, A.L.; Shifrina, Z.B. Preparation of soluble polyimides containing pendent imide groups. High Perform. Polym. 1993, 5, 107-121. [CrossRef]

18. Lin, S.-H.; Li, F.; Cheng, S.Z.D.; Harris, F.W. Organo-soluble polyamides: Synthesis and polymerization of 2,2'-bis(trifluoromethyl)-4,4',5,5'-biphenyltetracarboxylic dianhydride. Macromolecules 1998, 31, 2080-2086. [CrossRef]

19. Yeo, H.; Goh, M.; Ku, B.-C.; You, N.-H. Synthesis and characterization of highly-fluorinated colorless polyimides derived from 4,4'-((perfluoro-[1,1'-biphenyl]-4,4'-diyl)bis(oxy))bis(2,6-dimethylaniline) and aromatic dianhydrides. Polymer 2015, 76, 280-286. [CrossRef]

20. Hasegawa, M.; Ishigami, T.; Ishii, J. Optically transparent aromatic poly(ester imide)s with low coefficients of thermal expansion (1). Self-orientation behavior during solution casting process and substituent effect. Polymer 2015, 74, 1-15. [CrossRef]

21. Hasegawa, M.; Hirai, T.; Ishigami, T.; Takahashi, S.; Ishii, J. Optically transparent aromatic poly(ester imide)s with low coefficients of thermal expansion. 2: Effect of the introduction of alkyl-substituted p-biphenylene units. Polym. Int. 2018, 67, 431-444. [CrossRef]

22. Nam, K.-H.; Kim, H.; Choi, H.K.; Yeo, H.; Goh, M.; Yu, J.; Hahn, J.R.; Han, H.; Ku, B.-C.; You, N.-H. Thermomechanical and optical properties of molecularly controlled polyimides derived from ester derivatives. Polymer 2017, 108, 502-512. [CrossRef]

23. Yang, Q.; Chen, X.; He, Z.; Lan, F.; Liu, H. The glass transition temperature measurements of polyethylene: Determined by using molecular dynamic method. RSC Adv. 2016, 6, 12053-12060. [CrossRef]

24. Li, C.; Strachan, A. Molecular dynamics predictions of thermal and mechanical properties of thermoset polymer EPON862/DETDA. Polymer 2011, 52, 2920-2928. [CrossRef]

25. Lyulin, S.V.; Gurtovenko, A.A.; Larin, S.V.; Nazarychev, V.M.; Lyulin, A.V. Microsecond Atomic-Scale Molecular Dynamics Simulations of Polyimides. Macromolecules 2013, 46, 6357-6363. [CrossRef]

26. Liang, T.; Yang, X.; Zhang, X. Prediction of polyimide materials with high glass-transition temperatures. J. Polym. Sci. Part B-Polym. Phys. 2001, 39, 2243-2251. [CrossRef]

27. Mohammadi, M.; Fazli, H.; Karevan, M.; Davoodi, J. The glass transition temperature of PMMA: A molecular dynamics study and comparison of various determination methods. Eur. Polym. J. 2017, 91, 121-133. [CrossRef] 
28. Wang, Y.-H.; Wang, W.-H.; Zhang, Z.; Xu, L.; Li, P. Study of the glass transition temperature and the mechanical properties of PET/modified silica nanocomposite by molecular dynamics simulation. Eur. Polym. J. 2016, 75, 36-45. [CrossRef]

29. Sun, H. Compass: An ab initio force-field optimized for condensed-phase applications-Overview with details on alkane and benzene compounds. J. Phys. Chem. B 1998, 102, 7338-7364. [CrossRef]

30. Zheng, Q.; Xue, Q.; Yan, K.; Gao, X.; Li, Q.; Hao, L. Effect of chemisorption on the interfacial bonding characteristics of carbon nanotube-polymer composites. Polymer 2008, 49, 800-808. [CrossRef]

31. Yani, Y.; Lamm, M.H. Molecular dynamics simulation of mixed matrix nanocomposites containing polyimide and polyhedral oligomeric silsesquioxane (POSS). Polymer 2009, 50, 1324-1332. [CrossRef]

32. Frisch, M.J.; Trucks, G.W.; Schlegel, H.B.; Scuseria, G.E.; Robb, M.A.; Cheeseman, J.R.; Montgomery, J.A.; Vreven, T.; Kudin, K.N.; Burant, J.C.; et al. Gaussian 03 (Revision C.01); Gaussian, Inc.: Wallingford, CT, USA, 2004.

33. Nogi, M.; Kim, C.; Sugahara, T.; Inui, T.; Takahashi, T.; Suganuma, K. High thermal stability of optical transparency in cellulose nanofiber paper. Appl. Phys. Lett. 2013, 102, 181911.

34. Wu, C.; Xu, W. Atomistic molecular simulations of structure and dynamics of crosslinked epoxy resin. Polymer 2007, 48, 5802-5812. [CrossRef]

35. Morita, H.; Tanaka, K.; Kajiyama, T.; Nishi, T.; Doi, M. Study of the glass transition temperature of polymer surface by coarse-grained molecular dynamics simulation. Macromolecules 2006, 39, 6233-6237. [CrossRef]

36. Yang, H.; Li, Z.-S.; Qian, H.-J.; Yang, Y.-B.; Zhang, X.-B.; Sun, C.-C. Molecular dynamics simulation studies of binary blend miscibility of poly(3-hydroxybutyrate) and poly(ethylene oxide). Polymer 2004, 45, 453-457. [CrossRef]

37. Yu, K.-Q.; Li, Z.-S.; Sun, J. Polymer structures and glass transition: A molecular dynamics simulation study. Macromol. Theory Simul. 2001, 10, 624-633. [CrossRef]

38. Luo, Z.; Jiang, J. Molecular dynamics and dissipative particle dynamics simulations for the miscibility of poly(ethylene oxide)/poly(vinyl chloride) blends. Polymer 2010, 51, 219-299. [CrossRef]

(C) 2018 by the authors. Licensee MDPI, Basel, Switzerland. This article is an open access article distributed under the terms and conditions of the Creative Commons Attribution (CC BY) license (http:/ / creativecommons.org/licenses/by/4.0/). 